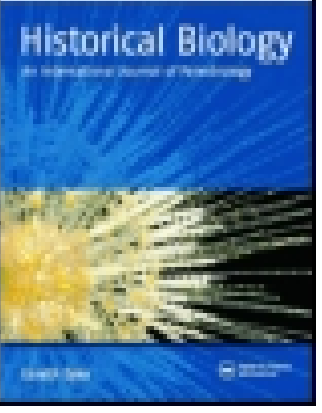

Historical Biology

An International Journal of Paleobiology

ISSN: 0891-2963 (Print) 1029-2381 (Online) Journal homepage: http://www.tandfonline.com/loi/ghbi20

\title{
Praeornis sharovi Rautian, 1978 a fossil feather from the early Late Jurassic of Kazakhstan
}

\section{Federico L. Agnolin, Sebastián Rozadilla \& Ismar de Souza Carvalho}

To cite this article: Federico L. Agnolin, Sebastián Rozadilla \& Ismar de Souza Carvalho (2017):

Praeornis sharovi Rautian, 1978 a fossil feather from the early Late Jurassic of Kazakhstan,

Historical Biology, DOI: 10.1080/08912963.2017.1413102

To link to this article: https://doi.org/10.1080/08912963.2017.1413102

$$
\text { Published online: } 11 \text { Dec } 2017 .
$$

Submit your article to this journal

Q View related articles $₫$

View Crossmark data $\asymp$ 


\title{
Praeornis sharovi Rautian, 1978 a fossil feather from the early Late Jurassic of Kazakhstan
}

\author{
Federico L. Agnolina,b, Sebastián Rozadillaa and Ismar de Souza Carvalhoc \\ aLaboratorio de Anatomía Comparada y Evolución de los Vertebrados, Museo Argentino de Ciencias Naturales "Bernardino Rivadavia”, Buenos Aires, \\ Argentina; 'bundación de Historia Natural “Félix de Azara", Universidad Maimónides, Buenos Aires, Argentina; 'Departamento de Geologia, Universidade \\ Federal do Rio de Janeiro, Rio de Janeiro, Brazil
}

\begin{abstract}
Since its original description as a feather belonging to a basal bird, the phylogenetic position of Praeornis sharovi was debated. It was considered as belonging to a bird, a cycad leaf, or as a'transitional'integumentary structure between reptile scales and bird feathers. Recently, a basal enantiornithine bird was collected in Early Cretaceous beds of Brazil. This specimen shows very well-preserved rachis-dominated tail feathers with a very thick rachis and thick and rigid barbules. These features are present in Praeornis, suggesting that this fossil may be interpreted as the tail feather of a basal bird. In this way, Praeornis constitutes one of the oldest records of rachis-dominated feathers in the world. Rachis-dominated tail feathers, including that of Praeornis appear to be rigid paired structures not performed for aerodynamical purposes, suggesting that may be important in body balance.
\end{abstract}

\section{ARTICLE HISTORY}

Received 24 October 2017

Accepted 30 November 2017

\section{KEYWORDS}

Praeornis sharovi; early Late Jurassic; Kazakhstan; rachisdominated tail feather

\section{Introduction}

The name Praeornis sharovi was coined by Rautian in 1978 on the basis of an isolated feather-like fossil. The specimen was originally found by the well-known paleontologist Aleksandr Grigorevich Sharov in 1971 in lower Upper Jurassic beds from Kazakhstan and was referred to it in a museum label as 'Praeornis'. Later, this taxon was formally described by Rautian (1978) whom noted its remarkable peculiarities, including the absence of barbules, and consequently named the new ad hoc. bird Subclass Praeornithes. After Rautian (1978) publication, several authors doubted the animal affiliation of this supposed feather. Bock (1986), Doludenko et al. (1990), and Wellnhofer (2004) argued that the specimen was a cycad leaf, and Nessov (1992) proposed that it was even a synonym of the species Cycadites sapportae. In this regard, Kellner (2002) indicates that feather affinities cannot be corroborated for this fossil. However, Glazunova et al. (1991) presented SEM evidence indicating the avian nature of Praeornis, a criterion followed by Kurochkin (2001), whereas Dzik et al. (2010), concluded that this taxon represents a feather thanks to the presence of isotope composition. It is worthy to note that Dzik et al. (2010) based their analysis not on the holotype specimen but on a referred isolated feather coming from the same locality and stratum. This unambiguously supports the original interpretation of Praeornis as an animal keratinous integumental structure, and not as a plant leaf.

Probably, one of the main reasons of the debated Praeornis affinities was its large size, and the fact that it was found in lower Upper Jurassic deposits. At the time of the description of Praeornis the Mesozoic bird record was mainly restricted to Archaeopteryx and the Latest Cretaceous toothed birds Ichthyornis, Herperornis, and its kin. In recent years the fossil record of Mesozoic birds has been dramatically increased mainly by the abundant record of China (Chiappe and Meng, 2016). More recently, a basal Enantiornithine was found in Early Cretaceous strata of Brazil (Carvalho et al. 2015a, 2015b). The specimen shows very well-preserved 3D tail feathers that allow to recognise and interpret several features of tail morphology in basal birds.

Because none of the previous authors compared Praeornis with the abundant evidence of fossil feathers coming from the Jurassic-Cretaceous deposits of China (Xu et al. 2010a; O'Connor et al. 2012) and Brazil (Carvalho et al. 2015a, 2015b) we think that a comparison may shed some light to Praeornis affinities. The aim of the present contribution is to discuss some aspects of Praeornis and to propose a new look at this controversial specimen.

Institutional abbreviations. PIN, Paleontological Institute of the Russian Academy of Sciences, Russia; UFRJ-DG Universidade Federal do Río de Janeiro, Department of Geology collection, Brazil.

\section{Locality and horizon}

The holotype of Praeornis sharovi comes from the fossiliferous locality of Aulie, above the village Kasharata (formerly Mikhailovka) (Hecker 1948), Republic of Kazakhstan. The locality is famous due to the finding of the pterosaur Sordes pilosus, which preserved 
integumental fibres (Sharov 1971; Unwin and Bakhurina 1994). Due to its important fossil findings, the locality was declared protected as a paleontological reserve (Galicky et al. 1968). The sediments that yielded Praeornis specimen belong to the top of the Karabastau Formation. This sedimentary unit was regarded by several authors as lower Upper Jurassic (Rasnitsyn and Zhang 2004; Vrsansky 2007), probably Oxfordian age (Zhang 2006).

\section{Results}

The holotype feather of Praeornis sharovi will not be described here, because it was described in great detail by previous authors (Rautian 1978; Kellner 2002; Dzik et al. 2010). Only main features and comments on important traits are made in some detail.

Dzik et al. (2010) reviewed in detail the specimen described by Rautian and pointed out the animal affinities for Praeornis. Dzik et al. (2010) and Sulej and Niedzwiedzki (2011) indicate that the specimen lacks any sign of vegetal structure and thus must be interpreted as a feather of an avian-like taxon. Furthermore, Dzik et al. (2010) referred to Praeornis another isolated structure coming from the same strata, although, due to some morphological differences are probably not the same taxon. Dzik et al. (2010) reported a 'third vane' on Praeornis, a feature that is not present in other known rachis-dominated feathers. However, this third vane was not observed by any previous author in the holotype specimen and is not visible from the photographs of the actual specimen. Since no living or fossil bird has three vanes on its feathers its presence in Praeornis seems unlikely.

Previous authors (e.g., Bock 1986; Wellnhofer 2004) considered that Praeornis was not a feather, mainly probably by its large size (the fragment of feather is nearly $15 \mathrm{~cm}$. long) and ancient age. In fact, by that time, only sparse avian records were described for the Jurassic and only Archaeopteryx from Solnhofen (Germany) stands as a Jurassic avialan (Bock 1986). However, the recent finding of a large variety and abundance of fossil skeletons of avian and non-avian theropods having different feather kinds have been reported from Jurassic and Cretaceous China (O’Connor et al. 2012) and Brazil (Carvalho et al. 2015a, 2015b), and invites us to take a new look at Praeornis.
Probably, one of the most peculiar recent findings of Mesozoic fossil feathers are the very long 'ribbon-like' feathers. This consists on 'rachis-dominated' elongate tail rectrices (see Zhang et al. 2006, 2008; O'Connor et al. 2012). As for Praeornis, these feathers are usually described as modified pennaceous feathers, showing a ribbon-like proximal half and a barbed distal portion (Wang et al. 2014). Birds with ribbon-like feathers include some confuciusornithids, enantiornithines, and the enigmatic scansoriopterygids (Hou et al. 1996; Chiappe et al. 1999; Chiappe and Walker 2002; Zhang et al. 2008; Xu et al. 2010a, 2010b; but see Prum 2010).

Praeornis shares with rachis-dominated feathers the large size, very large, and transversely expanded rachis with a longitudinal midline groove, ovoidal cross-section of the scapus, and very thick and convex barbules on distal vane (Rautian 1978; see Chuong et al. 2003; O'Connor et al. 2012; Figure 1). Moreover, distal vane without barbules is a feature shared by Praeornis and rachis-dominated feathers (Chiappe et al. 1999; Zhang and Zhou 2000). The rachis-dominated rectrices are currently represented by two main morphotypes (see Xu et al. 2010b; O'Connor et al. 2012): one including the oviraptorosaur Similicaudipteryx, and the other including basal birds and scansoriopterygids. The complex proximal morphology of the rectricial feathers indicates that PIN 2585/32 is similar to the second morphotype, whereas in Similicaudipteryx there is not recognizable rachis and its scapus shows an abrupt wedge-like connection with the pennaceous distal end. It is worthy to mention that the supposed rachis-dominated feathers of Similicaudipteryx may be molting feathers (Prum 2010; Foth 2012; O'Connor et al. 2012). Within birds having rachis-dominated feathers, two different types can be distinguished: that present in Confuciusornithids and most Enantiornithes, in which the rachis is proximally naked, lacking any sign of barbs, and a second subtype present in pengornithids which show rachis-dominated rectrices having barbs along the entire rachis (O'Connor et al. 2012; Carvalho et al. 2015a) (Figure 2).

In this way, Praeornis cannot be distinguished by any character of its gross or detailed morphology from the rachisdominated like feathers reported in several basal birds (O'Connor et al. 2012).
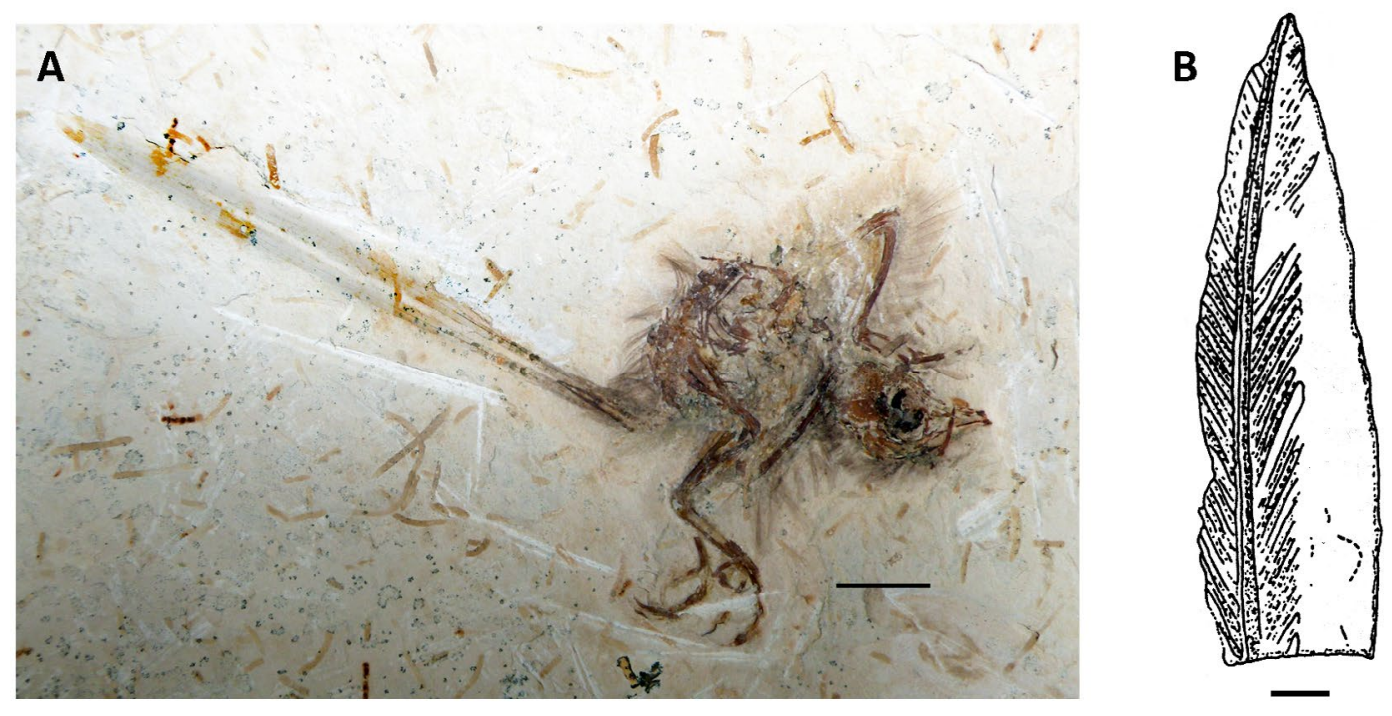

Figure 1. A, Holotype of Cratoavis cearensis (UFRJ-DG 031), B, Original illustration of Praeornis (modified from Rautian 1978). 


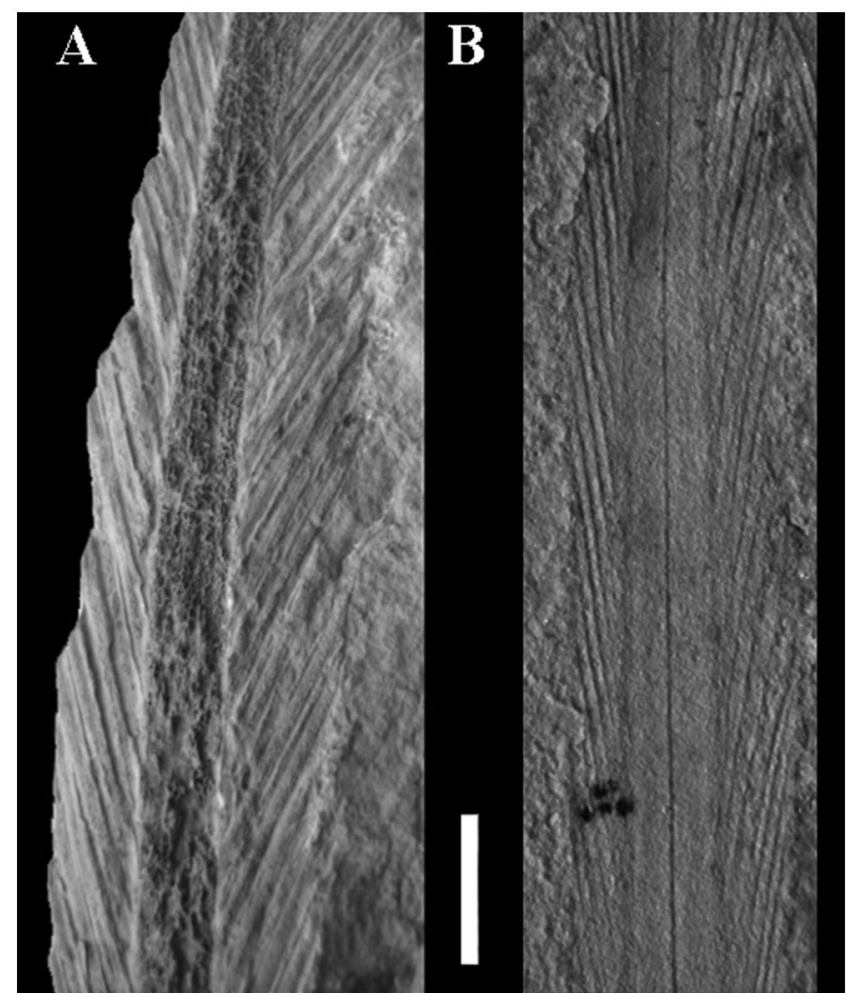

Figure 2. A-B, rectricial rachis-dominated tail feathers of $A$, Praeornis sharovi (PIN 2585/32, holotype), B, UFRJ-DG 031 Av, indeterminate Enantiornithes. Scale bar: $A=1 \mathrm{~cm} ; B=0.2 \mathrm{~cm}$.

\section{Discussion}

Almost all known Early Cretaceous non-Ornithuromorpha pygostylians preserving feathers (i.e., confuciusornithids, enantiornithes), show an enigmatic kind of tail formed by a pair of elongate rectrices known as 'ribbon-like' or 'rachis-dominated' feathers, which are unknown in living birds (Prum 2010; Xu et al. 2010a; O'Connor et al. 2012). These feathers consist on a ribbon-like proximal half with a barbed distal portion, which contrasts with the morphology of Sapeornis, basal ornithuromorphs, some enantiornithines, which have a fan-shaped tail made up by a series of short rectrices, resembling that present in living birds (O'Connor et al. 2012). Basic anatomical aspects of the ribbon-like type feathers are still difficult to interpret. One of the main reasons is the absence of this kind of feather among living birds (O'Connor et al. 2012). In spite of different hypotheses regarding the structure of these feathers (e.g., Zhou and Zhang 2000; Zhang et al. 2008; Prum 2010; Xu et al. 2010a, 2010b; O'Connor et al. 2012), most authors concur that the rachis-dominated feathers are in agreement with the developmental mode of feather origins proposed by Prum (1999). On the contrary, some authors consider that feathers may have originated by differentiation of reptilian scales (Jones et al. 2000; Dzik et al. 2010; Sulej and Niedzwiedzki 2011). In this line of thought, Dzik et al. (2010) argued that Praeornis may be a link connecting reptilian scales from a Longisquama-like reptile with avian feathers. However, the recognition of Praeornis as a rachis-dominated rectricial feather argues against the evolutionary scenario proposed by Dzik et al. (2010) and Sulej and Niedzwiedzki (2011).

Since the discovery of ribbon-like elongate feathers in Confuciusornis, authors mostly agreed that such elongate structures may be associated with sexual display or visual communication (Chiappe et al. 1999; Zhang and Zhou 2000; Clarke et al. 2006; Li et al. 2006; Zheng et al. 2007; Chiappe et al. 2008; Li et al. 2012; O'Connor et al. 2011; Padian and Horner 2011; $\mathrm{O}^{\prime}$ Connor et al. 2012, 2013). In living birds with elongate forked tail, the rectrices change their angle of attack and angle of spread, and thus, the tail streamers retain an aerodynamic function (e.g., Balmford et al. 1994; Thomas 1997; Tubaro 2003). Furthermore, as early recognised, rachis-dominated feathers are sharply different from these tail feathers (Xu et al. 2010a, 2010b): in confuciusornithids and Enantiornithes the rachis-dominated rectrices are always preserved subparallel each other. They seem to be a rigid structure (Carvalho et al. 2015a, 2015b), having distal symmetrical vanes composed of very thick and probably rigid barbs. The very thick and rigid rachis and general morphology of this kind of tail feather indicate that it was not probably aerodynamical performed, and evidence at hand suggest that the paired rectrices may not spread as in living birds (Carvalho et al. 2015a, 2015b). This suggests, as proposed by previous authors (Choung et al. 2013), that rachis-dominated feathers may be not exclusively associated to the sexual display, but also could assist the body balance when the birds was perching, compensating the loss of weight due to the reduction of the long bony tail in ornithurine birds (Chuong et al. 2013). Moreover, Hu and collaborators (2015) propose that these rigid structures could also work for stabilisation during trunk climbing.

With respect to taxa with intraspecific variation in the presence or absence of rachis-dominated feathers (e.g. Confuciusornis) and interpreted by some authors as the result of sexual dimorphism (Hou et al. 1996; Martin et al. 1998; Chiappe et al. 1999; Hou et al. 1999; but see Chiappe et al. 2008), may be alternatively interpreted as being the result of feather moulting. In numerous extant birds, when the feather moulting occurs in wings and tail, the change occurs in paired feathers, following bilateral symmetry (Owen and Ogilvie 1979). Considering that the rachis-dominated feathers are paired structures, the moulting should be simultaneous in both feathers. If the rachis-dominated feathers are indeed, important to the body balance when the bird is perching, the loss of these could imply that the behaviour of the bird should change and settle to its new condition, as occurs in many extant birds (e.g. Anseriformes, Phoenicopteriformes; Allen 1956; Salomonsen 1968; Palmer 1972; Fox and King 2011). However, more evidence is needed in order to sustain this hypothesis.

Documentation of a rachis-dominated feather from Kazakhstan expands the paleobiogeographic distribution of this kind of elongate tail feathers, up to now only reported from China, Spain and Brazil (e.g. Kellner 2002; Marugán-Lobón and Vullo 2011; Carvalho et al. 2015a, 2015b). Furthermore, the early Late Jurassic age of Praeornis posits it as one of the oldest findings of rachis-dominated feathers, together with similar-aged scansoriopterygids from China (Zhang et al. 2008).

\section{Acknowledgements}

We thank F. Novas, N. Chimento, G. Lio, Matías J. Motta and S. Lucero for sharing several discussions regarding avian anatomy and feather morphology of extant birds. We also thank Sergio Bogan (Fundación de Historia Natural 'Félix de Azara') for allowing the study of the collections under his 
care. Special thanks to Tomasz Sulej for sending photographs and information on the holotype specimen of Praeornis sharovi. We are indebted to the comments and corrections to the manuscript made by the reviewers, A. Averianov, C. Foth, C. Laurent, and G. Dyke.

\section{Disclosure statement}

No potential conflict of interest was reported by the authors.

\section{References}

Allen RP. 1956. The flamingoes-their life history and survival. Res Rep. No. 5. New York, NY: National Audubon Society.

Balmford A, Jones IL, Thomas ALR. 1994. How to compensate for sexuallyselected tails: the evolution of sexual dimorphism in wing length in long-tailed birds. Evolution. 48:1062-1070.

Bock W. 1986. The arboreal origin of avian flight. In: Padian K, editor. The origin of birds and the evolution of flight. Vol. 8. San Francisco (CA): Memoirs of the California Academy of Sciences; p. 57-72.

Carvalho IDS, Novas FE, Agnolín FL, Isasi MP, Freitas FI, Andrade JA. 2015a. A Mesozoic bird from Gondwana preserving feathers. Nat Commun. 6:7141.

Carvalho IDS, Novas FE, Agnolín FL, Isasi MP, Freitas FI, Andrade JA. 2015b. A new genus and species of enantiornithine bird from the Early Cretaceous of Brazil. Braz J Geol. 45(2):161-171.

Chiappe LM, Ji S, Ji Q, Norell MA. 1999. Anatomy and systematics of the Confuciusornithidae (Theropoda: Aves) from the late mesozoic of northeastern China. Bull Am Mus Nat Hist. 242:1-89.

Chiappe LM, Marugán-Lobón J, Ji S, Zhou Z. 2008. Life history of a basal bird: morphometrics of the Early Cretaceous. Confuciusornis. Biol Lett. 4:719-723.

Chiappe LM, Walker A. 2002. Skeletal morphology and systematics of the Cretaceous Euenantiornithes (Ornithothoraces: Enantiornithes). In: Chiappe LM, Witmer L, editors. Mesozoic birds: above the heads of dinosaurs. Berkeley: Univ. California Press; p. 240-267.

Chiappe LM, Meng Q. 2016. Birds of Stone: Chinese Avian Fossils from the Age of Dinosaurs. Johns Hopkins University Press.

Chuong CM, Wu P, Zhang FC, Xu X, Yu M, Widelitz RB, Jiang TX, Hou L. 2003. Adaptation to the sky: defining the feather with integument fossils from mesozoic China and experimental evidence from molecular laboratories. J Exp Zool B Mol Dev Evol. 298:42-56.

Chuong Cheng-Ming, Yeh Chao-Yuan, Ting-Xin Jiang, Widelitz Randall. 2013. Module-based complexity formation: periodic patterning in feathers and hairs. Wiley Interdisciplinary Reviews: Developmental Biology. 2(1):97-112.

Clarke JA, Zhou Z, Zhang F. 2006. Insight into the evolution of avian flight from a new clade of Early Cretaceous ornithurines from China and the morphology of Yixianornis grabaui. J Anatomy. 208:287-308.

Doludenko MP, Sakulina GV, Ponomarenko AG. 1990. Geologicheskoye stroyenie rayona unikalnogo mestonakhozhdenia posdnejurskoy fauny i flory aule (Karatau, southern Kazakhstan). Moskva: Geologicheskiy Institut AN SSSR.

Dzik J, Sulej T, Niedzwiedzki G. 2010. Possible link connecting reptilian scales with avian feathers from the early Late Jurassic of Kazakstan. Hist Biol. 22:394-402.

Foth C. 2012. On the identification of feather structures in stem-line representatives of birds: evidence from fossils and actuopalaeontology. Paläont Zeits. 86:91-102.

Fox AD, King R. 2011. Body mass loss amongst moulting Pochard Aythya ferina and Tufted Duck A. fuligula at Abberton Reservoir, South East England. J Ornith. 152(3):727-732.

Galicky VV, Hecker RF, Kostenko NN, Sakulina GV. 1968. Karatauskoye jurskoye ozero. Putevoditel ekskursyi piatoy paleoekologolitologicheskoy sesyi na jurskie otlozhenia khrebta Karatau v Yuzhnom Kazakhstanie. 14-19.

Glazunova KP, Rautian AS, Filin VR. 1991. Praeornis sharovi: bird feather or plant leaf? Materialy 10 Vsesoyuznoi Ornitologicheskoi Konferentzii, Vitebsk: 17-20 sentjabrya 1991 Chast 2, 1, 149-150. Minsk: Nauka i tekhnika.
Hecker RF. 1948. Karatauskoye mestonakhozhdenie fauny i flory jurskogo vozrasta. Trudy Paleont Inst AN SSSR. 15:7-85.

Hou L, Martin LD, Zhou Z, Feduccia A. 1996. Early adaptive radiation of birds: evidence from fossils from Northeastern China. Science. 274:1164-1167.

Hou L, Martin LD, Zhou Z-H, Feduccia A, Zhang F. 1999. A diapsid skull in a new species of the primitive bird Confuciusornis. Nature. 399:679682.

Hu H, O'Connor JK, Zhou ZH. 2015. A new species of pengornithidae (Aves: Enantiornithes) from the lower cretaceous of China suggests a specialized scansorial habitat previously unknown in early birds. PLOS One. 10(6):e0126791.

Jones TD, Ruben JA, Martin LD, Kurochkin EN, Feduccia A, Maderson PFA, Hillenius WJ, Geist NR, Alifanov V. 2000. Nonavian feathers in a late Triassic archosaur. Science. 288:2202-2205.

Kellner AWA. 2002. A review of avian Mesozoic fossil feathers. In: Chiappe LM, Witmer LM, editors. Mesozoic Birds: above the head of dinosaurs. Berkeley: University of California Press; p. 389-404.

Kurochkin E. 2001. Mesozoic birds of Mongolia and the former USSR. In: Benton MJ, Shishkin MA, Unwin DM, Kurochkin E, editors. The age of dinosaurs in Russia and Mongolia; p. 533-559.

Li L, Duan Y, Hu D, Wang L, Cheng S, Hou L. 2006. New Eoenantiornithid Bird from the Early Cretaceous Jiufotang Formation of Western Liaoning, China. Acta Geol Sin. 80(1):38-41.

Li L, Wang J, Zhang X, Hou S. 2012. A New Enantiornithine Bird from the Lower Cretaceous Jiufotang Formation in Jinzhou Area, Western Liaoning Province, China. Acta Geol Sin. 86(5):1039-1044.

Martin LD, Zhou ZH, Hou L, Feduccia A. 1998. Confuciusornis sanctus compared to Archaeopteryx lithographica. Naturwissenschaften. 85:286-289.

Marugán-Lobón J, Vullo R. 2011. Feather diversity in the Barremian (Early Cretaceous) of Las Hoyas, Spain. Comptes Rendus Palevol. 10(4):219223.

Nessov LA. 1992. Mesozoic and Paleogene birds of the USSR, and their paleoenvironments. In: Campbell KE Jr, editor. Papers on avian Paleontology honouring Pierce Brodkorp. Los Angeles, CA: Natural History Museum of Los Angeles County; p. 465-478.

O'Connor JK, Chiappe LM, Chuong C, Bottjer DJ, You H. 2012. Homology and potential cellular and molecular mechanisms for the development of unique feather morphologies in early birds. Geosciences. 2:157-177.

O'Connor JK, Zhou Z, Zhang F. 2011. A reappraisal of Boluochia zhengi (Aves: Enantiornithes) and a discussion of intraclade diversity in the Jehol avifauna, China. J Syst Palaeont. 9:51-63.

O'Connor Jingmai K, Zhang Yuguang, Chiappe Luis M, Meng Qingjin, Quanguo Li, Di Liu. 2013. A new enantiornithine from the Yixian Formation with the first recognized avian enamel specialization. J Vert Paleont. 33(1):1-12.

O'Connor JK, Wang XR, Chiappe LM, Gao CH, Meng QJ, Cheng XD, Liu JY. 2009. Phylogenetic support for a specialized clade of Cretaceous enantiornithine birds with information from a new species. J Vert Paleont. 29:188-204.

Owen M, Ogilvie MA. 1979. Wing molt and weights of barnacle geese in Spitsbergen. The Condor. 81(1):42-52.

Padian K, Horner J. 2011. The evolution of 'bizarre structures' in dinosaurs: biomechanics, sexual selection, social selection, or species recognition? J Zool. 283:3-17.

Palmer RS. 1972. Patterns of moulting. In: Farner DS, King JR, editors. Avian Biology. Vol. 2. New York and London: Academic Press; p. 65102.

Prum RO. 1999. Development and evolutionary origin of feathers. J Exp Zool. 285:291-306.

Prum RO. 2010. Moulting tail feathers in a juvenile oviraptorisaur. Nature. 468:E1.

Rasnitsyn A, Zhang HC. 2004. Composition and age of the Daohugou hymenopteran (Insecta, Hymenoptera-Vespida) assemblage from inner Mongolia, China. Palaeontology. 47:1507-1517.

Rautian AS. 1978. A unique bird feather from Jurassic lake deposits in the Karatau. Palaeontol J. 4:520-528.

Salomonsen F. 1968. The moult migration. Wildfowl. 19:5-24.

Sharov AG. 1971. Novyie letayushchiye reptilii iz mezozoya Kazakhstana i Kirgizyi. Trudy Paleont Inst AN SSSR. 130:104-113. 
Sulej T, Niedzwiedzki G. 2011. Jak powstato ptasie pióro? Ewolucja. 4:3436.

Thomas ALR. 1997. On the tails of birds. Bioscience. 47:215-225.

Tubaro PL. 2003. A comparative study of aerodynamic function and flexural stiffness of outer tail feathers in birds. J Avian Biol. 34:243-250.

Unwin DM, Bakhurina NN. 1994. Sordes pilosus and the nature of the pterosaur flight apparatus. Nature. 371:62-64.

Vrsansky P. 2007. Jumping cockroaches (Blattaria, Skokidae fam. n.) from the late Jurassic of Karatau in Kazakhstan. Biol. 62:588-592.

Wang Xiaoli, O'Connor Jingmai K, Zheng Xiaoting, Wang Min, Han Hu, Zhou Zhonghe. 2014. Insights into the evolution of rachis dominated tail feathers from a new basal enantiornithine (Aves: Ornithothoraces). Biol J Linnean Soc. 113(3):805-819.

Wellnhofer P. 2004. The plumage of Archaeopteryx: feathers of a dinosaur. In: Currie Koppelhus Shugar and Wright, editors. Feathered Dragons: Studies on the Transition from Dinosaurs to Birds. Indiana University Press; p. 282-300.
Xu X, Zheng XT, You HL. 2010a. Exceptional dinosaur fossils show ontogenetic development of early feathers. Nature. 464:1339-1341.

Xu X, Zheng XT, You HL. 2010b. Reply: Moulting tail feathers in a juvenile oviraptorosaur. Nature. 468:E2.

Zhang J. 2006. New winter crane flies (Insecta: Diptera: Trichoceridae) from the Jurassic Daohugou Formation (Inner Mongolia, China) and their associated biota. Can J Earth Sci. 43:9-22.

Zhang FC, Zhou Z. 2000. A primitive enantiornithine bird and the origin of feathers. Science. 290:1955-1959.

Zhang FC, Zhou ZG, Dyke G. 2006. Feathers and 'feather-like' integumentary structures in Liaoning birds and dinosaurs. Geol J. 41:395-404.

Zhang F, Zhou Z, Xu X, Wang X, Sullivan C. 2008. A bizarre Jurassic maniraptoran from China with elongate ribbon-like feathers. Nature. 455(7216):1105-1108.

Zheng X, Zhang Z, Hou L. 2007. A new enantiornitine bird with four long rectrices from the Early Cretaceous of northern Hebei, China. Acta Geol Sin. 81:703-708. 